\title{
Effects of Biogas Slurry Utilization in Long-Term on Soil Nutrients and Enzyme Activities
}

\author{
Wu Jichengab ${ }^{1,2 *}$, Pan Xiaoyingab ${ }^{1,2}$, Yang Yonghuiab ${ }^{1,2}$, Gao Cuiminab ${ }^{1,2}$, Wang Yueab ${ }^{1,2}$ and Li Minjieac $^{1,3}$ \\ ${ }^{1}$ Institute of Plant Nutrition \& Resource Environment, Henan Academy of Agricultural Sciences, China
}

${ }^{2}$ Yuanyang Experimental Station of Crop Water Use, Ministry of Agriculture, China

${ }^{3}$ Agricultural College of Zhengzhou University, China

*Corresponding author: Wu Jichenga, Institute of Plant Nutrition \& Resource Environment, Henan Academy of Agricultural Sciences, China

\begin{abstract}
In order to find out the effect of biogas slurry utilization in long-term on soil nutrient and soil enzyme activity, the typical breeding enterprises of biogas slurry utilization in Henan Province was investigated by April and October 2019. The results showed that the content of organic matter, nitrogen, phosphorus and potassium in biogas slurry was relatively low, including $0.26 \mathrm{~g} / \mathrm{l}$ of organic matter, $1.27 \mathrm{~g} / \mathrm{l}$ of total nitrogen, $0.19 \mathrm{~g} / \mathrm{l}$ of total phosphorus and $0.94 \mathrm{~g} / \mathrm{l}$ of total potassium. After years later by biogas slurry irrigation and application, the nutrient factors of the soil surface layer were improved, among which the organic matter in the soil surface layer increased by $0.2-27.9 \mathrm{~g} / \mathrm{kg}$, the total nitrogen increased by $0.02-2.7 \mathrm{~g} / \mathrm{kg}$, and the total phosphorus increased by $0.1-3.25 \mathrm{~g} / \mathrm{kg}$ the mode of combining the biogas residue with the biogas liquid of KANGLONG biogas was the largest one. Total potassium increased by $0.2-5.53 \mathrm{~g} / \mathrm{kg}$, with an increase of $1.14-28.10 \%$ which of YOULIN was the largest one. The value of $\mathrm{pH}$ changed to conducive to soil nutrient release. The accumulation of available $\mathrm{P}$ in soil is increased by $9.18-108.7 \mathrm{mg} / \mathrm{kg}$, which is consistent with the trend of organic matter and total $\mathrm{P}$ content. The hydrolyzed $\mathrm{N}$ is increased by $0.2-156.79 \mathrm{mg} / \mathrm{kg}$, which is consistent with the trend of organic matter and total $\mathrm{N}$ content, and the available $\mathrm{K}$ is increased by $19.23-109.45 \mathrm{mg} / \mathrm{kg}$, which is consistent with the trend of total $\mathrm{K}$. That all are the results of long-term accumulation by use of biogas slurry. The activities of soil hydrolase and oxidoreductase significantly were increased by use of biogas slurry. Compared with the control farmland, protease increased by $0.49-4.02 \mathrm{IU} / \mathrm{L}$, increased by $8.77-64.42 \%$, invertase increased by $51.34-235.25 \mathrm{IU} / \mathrm{L}$, increased by $11.24-41.83 \%$, urease increased by 71.78-374.54IU/L, increased by 10.55-49.12\%, acid phosphatase increased by $1.49-14.77 \mathrm{IU} / \mathrm{L}$, increased by 5.16-45.86\%, cellulase increased by 2.51-58.81IU/L, It increased by 2.72-61.40\%, nitrate reductase by $0.48-9.82 \mathrm{IU} / \mathrm{L}, 3.51-55.95 \%$, nitrite reductase by $0.7312 .89 \mathrm{IU} / \mathrm{L}, 2.34-51.47 \%$, dehydrogenase by $0.11-3.88 \mathrm{IU} / \mathrm{L}, 3.51-62.19 \%$, catalase by $2.93-32.77 \mathrm{IU} / \mathrm{L}, 4.33-$ $46.18 \%$. There was a significant correlation between soil nutrients and enzyme activity, among which soil organic matter, N, P, K, dehydrogenase and catalase activities were all positively correlated, soil total $\mathrm{N}$, hydrolyzed $\mathrm{N}$, available $\mathrm{P}$ and cellulase were also positively correlated, organic matter, available $\mathrm{K}$ and cellulase were significantly correlated. At the same time, there are significant or extremely significant correlation between different soil enzymes.
\end{abstract}

Keyword: Biogas slurry; Biogas slurry utilization; Soil nutrients; Soil enzyme activity; Long-Term; Eutrophication

\section{Introduction}

Biogas slurry is the liquid residue of anaerobic fermentation of livestock manure, crop straw and other organic matters. It only contains available $\mathrm{N}, \mathrm{P}, \mathrm{K}$, and is also rich in trace elements such as $\mathrm{S}, \mathrm{Ca}, \mathrm{Mg}$, humic acid, amino acid, organic matter, et a [1,2]. Biogas slurry can not only improve the soil, improve the soil nutrient status $[3,4]$, promote the growth and development of crops $[5,6]$, and improve crop photosynthetic characteristics $[7,8]$, and improve crop yield and quality [9-11]. And which can also affect nitrogen absorption and water consumption, and improve protein content, dry matter accumulation and nitrogen use efficiency of winter wheat [12-15] and reduce soil C / N mineralization and greenhouse gas emission [16]. More importantly, by use of biogas slurry, it can also improve the biological characteristics of soil [17], and improve the activity of soil enzymes [18-20], and then affect the activity indexes of soil quality and the evaluation indexes of soil fertility, and play an important role in the soil ecosystem [21]. Therefore, biogas slurry is considered to be a good organic fertilizer and the 
best alternative product for increasing crop yield and nutrients [22]. However, a large number of long-term irrigation and application of biogas slurry, because of its rich and effective nutrients, is very easy to cause soil nitrogen and phosphorus accumulation, and form environmental problems such as point and surface soil pollution and water eutrophication. Furthermore, scientific and reasonable biogas slurry irrigation can slow down the over eutrophication of farmland fertility [23], and improve soil microbial biomass and activity $[24,25]$, so as to realize the sustainable utilization of soil. The output of biogas slurry is more than 300 million tons per year in Henan Province. There have different ways of using biogas slurry, crops and consumption in different enterprises. In order to make better use of biogas slurry, avoid secondary pollution caused by biogas slurry irrigation, and reveal the impact of biogas slurry utilization on soil nutrients and enzyme activity, we have sampled and analyzed the soil of biogas slurry utilization with different service life, consumption and planting methods. It is expected to provide scientific basis for the scientific utilization of biogas slurry and soil fertility.

\section{Samples Collection and Analysis}

According to the development scale of the aquaculture industry and the utilization of biogas residue and biogas slurry, the soil samples of $0-100 \mathrm{~cm}$ of 11 representative aquaculture industries in Henan Province were respectively collected from the biogas slurry utilization plot and the control farmland plot in April and October 2019, which were naturally dried, and then crushed to test and analyze their organic matter, $\mathrm{pH}$, total and effective nitrogen, phosphorus, potassium, nitrate nitrogen, soil enzyme activity, et al, which soil organic matter is determined by potassium dichromate volumetric method, the total nitrogen by semi-micro kelvin method, the total phosphorus and available phosphorus by molybdenum antimony colorimetric method, the total potassium and available potassium atomic absorption spectrometry, the hydrolyzed nitrogen by alkaline solution distillation potentiometric titration method, the nitrate nitrogen by ultraviolet spectrophotometric method, and the soil enzyme activity byadopt corresponding enzyme activity kit for analysis (Table 1).

Table 1: Utilization of biogas slurry in different enterprises.

\begin{tabular}{|c|c|c|c|c|c|}
\hline Enterprises & Years & Volume t/per time & Raw materials & Modes & Plants \\
\hline Ruixiang(rx) & 9 & 40 & Pig manure & Biogas slurry and residue & Greenhouse vegetable \\
\hline Maiduo(md) & 5 & $35-40$ & Cow manure & Biogas slurry & Greenhouse vegetable \\
\hline Songguilang(sgl) & 8 & $30-35$ & Pig manure & Biogas slurry and residue & Corn-vegetable \\
\hline Taozhiyuan(tzy) & 5 & 40 & Pig manure & Biogas slurry & Peach \\
\hline Guoxing(gx) & 7 & $40-45$ & Chicken manure & Biogas slurry & Wheat-corn \\
\hline Juxing(jx) & 8 & $30-35$ & Pig and cow manure & Biogas slurry & Greenhouse vegetable \\
\hline Xinjing(xj) & 12 & $30-40$ & Pig manure & Biogas slurry & Grape \\
\hline Yifa(yf) & 15 & $30-40$ & Pig manure & Biogas slurry & Wheat-corn \\
\hline Youlin(yl) & 5 & $30-35$ & Pig manure & Biogas slurry & Grape \\
\hline Fengrun(fr) & 12 & 35 & Pig manure & Biogas slurry & Grape \\
\hline Kanglong(kl) & 12 & $30-35$ & Pig manure & Biogas slurry and residue & Greenhouse vegetable \\
\hline Xinzhengde(xzd) & 12 & $25-35$ & Pig manure & Biogas slurry and residue & Wheat-millet \\
\hline
\end{tabular}

\section{Results and analysis}

Nutrient characteristics of biogas slurry of different aquaculture enterprises in Henan Province

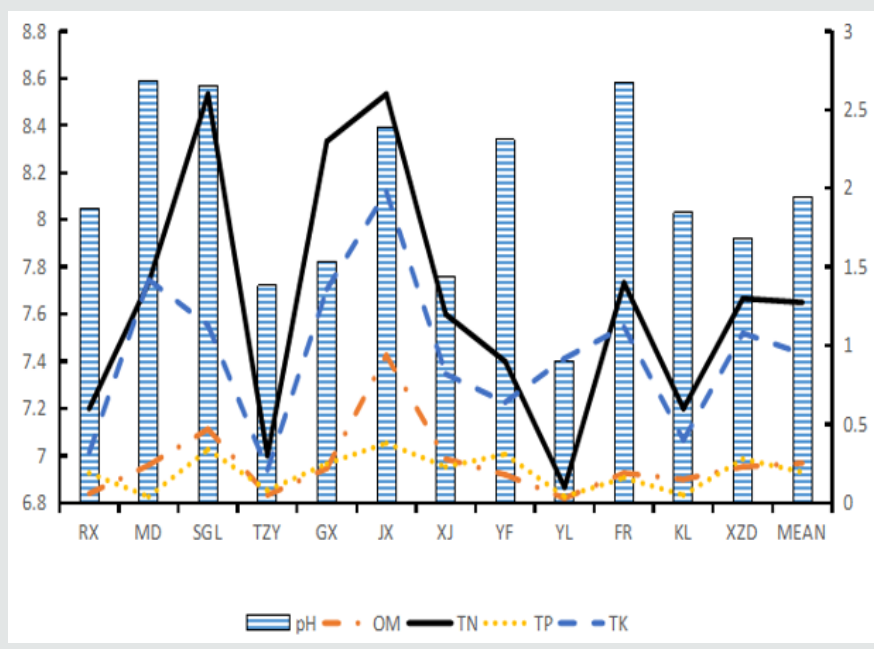

Figure 1: The content of OM, TN, TP and TK in different biogas slury (g/L) of different enterprises. 
There are obvious differences in organic matter, total nitrogen, total phosphorus, total potassium and $\mathrm{pH}$ value in biogas slurry of different aquaculture enterprises (Figure 1). The average content of organic matter is $0.26 \mathrm{~g} / \mathrm{L}$, and the highest is $0.94 \mathrm{~g} / \mathrm{L}$, the lowest is only $0.03 \mathrm{~g} / \mathrm{L}$. The average content of total nitrogen is $1.27 \mathrm{~g} / \mathrm{L}$, and the highest is $2.6 \mathrm{~g} / \mathrm{L}$, the lowest is $0.3 \mathrm{~g} / \mathrm{L}$. The average content of total phosphorus is $0.19 \mathrm{~g} / \mathrm{L}$, and the highest is $0.38 \mathrm{~g} / \mathrm{L}$, the lowest is $0.04 \mathrm{~g} / \mathrm{L}$. The average content of total potassium is $0.94 \mathrm{~g} / \mathrm{L}$, and the highest is $1.98 \mathrm{~g} / \mathrm{L}$, the lowest is $0.40 \mathrm{~g} / \mathrm{L}$. In a word, the nutrient components of biogas slurry irrigated by different enterprises are quite different. The sources of organic matter, total nitrogen, total phosphorus and total potassium are all low, including KL, YL, RX and TZY. The sources of organic matter, total nitrogen, total phosphorus and total potassium are all high, including JX and SGLG. The sources of total phosphorus is low, but the organic matter and total nitrogen, phosphorus and potassium are high, including MD. That of the others enterprises are all in the middle level.

\section{Effects of biogas slurry utilization on soil organic matter, pH and NPK}

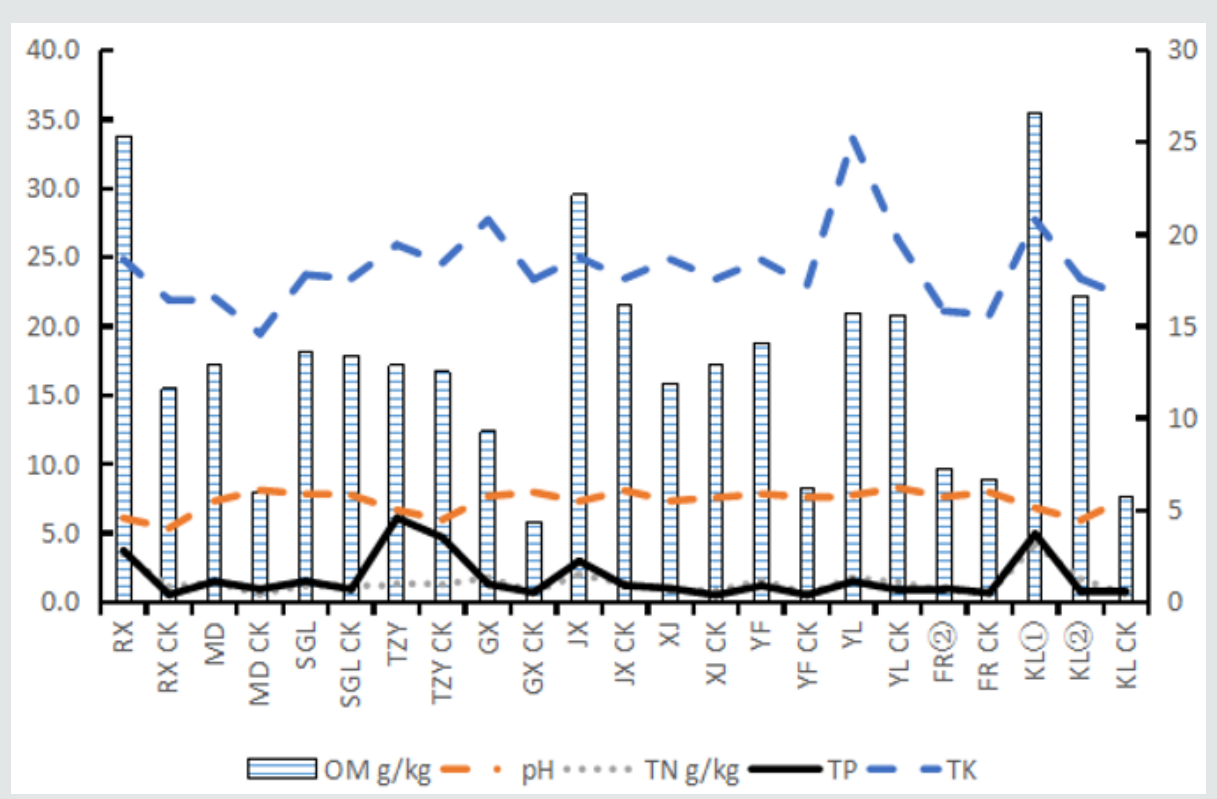

Figure 2: Effect of biogas slurry application on soil OM, TN, TP, TK (g\kg) and PH Value.

Soil pH, organic matter, total nitrogen, total potassium, total phosphorus, available nitrogen, nitrate nitrogen, available phosphorus and available potassium are effectively improved by biogas slurry utilization (Figure 2), but there are significant differences between different nutrient factors. The soil surface organic matter increased by $0.2 \mathrm{~g} / \mathrm{kg}$ to $27.9 \mathrm{~g} / \mathrm{kg}$, with an increase of $0.96 \%$ to $367.11 \%$. The mode of combining the biogas residue and liquid of KL was the most significant. However, the soil organic matter of XJ decreased by $1.3 \mathrm{~g} / \mathrm{kg}$, a decrease of $7.56 \%$, which the main reason was that the vineyard was formed by wasteland development, but the forest land(CK) was not affected by human farming activities, and the litter layer was obvious. The $\mathrm{pH}$ value of soil increased and decreased respectively, that of MD, JX, KL, YL, FR, GX and XJ decreased by $0.79,0.78,0.720 .53,0.33,0.29$ and 0.24 respectively, with a decrease range of $9.69 \%, 9.61 \%, 9.49 \%, 6.37 \%$, $4.13 \%, 3.63 \%$ and $3.15 \%$, that of RX, TZY, YF and SGL increased by $0.74,0.70,0.24$ and 0.07 respectively, the decrease range is $13.73 \%$, $11.65 \%, 3.14 \%$ and $0.90 \%$ respectively. The increase or decrease is in favor of the release of soil nutrients, such as the change from acid to weak alkaline in RX and from alkaline to weak alkaline in MD.

The content of total nitrogen, total phosphorus and total potassium in the surface soil increased significantly. The total nitrogen increased by $0.02 \mathrm{~g} / \mathrm{kg}$ to $2.7 \mathrm{~g} / \mathrm{kg}$, an increase of $2.15 \%$ to $600 \%$, the total phosphorus increased by $0.1 \mathrm{~g} / \mathrm{kg}$ to $3.25 \mathrm{~g} / \mathrm{kg}$, an increase of $12 \%$ to $663.27 \%$, and the greatest increase was the mode of combining the biogas residue and liquid of KL. Total potassium increased by $0.2 \mathrm{~g} / \mathrm{kg}$ to $5.53 \mathrm{~g} / \mathrm{kg}$, an increase of $1.14 \%$ to $28.10 \%$, and YL increased the most.

In terms of the biogas slurry utilization time, the organic matter, total nitrogen and total potassium of the greenhouse vegetables were $\mathrm{KL}>\mathrm{RX}>\mathrm{MD}>\mathrm{JX}$, except MADUO with low basic nutrients, the increase was basically increased with the increase of time, the total phosphorus was increased with the increase of utilization time, that is $\mathrm{KL}>\mathrm{RX}>\mathrm{JX}>\mathrm{MD}$. The organic matter, total nitrogen and total phosphorus of the mode of grain economy were $\mathrm{YF}>\mathrm{GX}>$ $\mathrm{SGL}$, soil total potassium is $\mathrm{GX}>\mathrm{YF}>\mathrm{SGL}$, which is related to its low basic nutrients. The mode of orchard planting is the most complex, soil organic matter is $\mathrm{FR}>\mathrm{TZY}>\mathrm{YL}>\mathrm{XJ}$, soil total nitrogen is $\mathrm{FR}>$ $\mathrm{YL}>\mathrm{XJ}>\mathrm{TZY}$, soil total phosphorus is $\mathrm{XJ}>\mathrm{YL}>\mathrm{FR}>\mathrm{TZY}$, soil total potassium is $\mathrm{YL}>\mathrm{XJ}>\mathrm{TZY}$, which may be related to the amount and times of irrigation.

The available phosphorus are all increased, while the hydrolyzed nitrogen and available potassium decreased only in TZY (Figure 3 ), which was related to the large-scale use of chemical fertilizer by farmers for planting medicinal materials, while the others all increased, the nitrate nitrogen increased and decreased differently. 
The accumulation of available phosphorus increased rapidly due to the large amount of biogas slurry irrigation, which increased by $9.18 \mathrm{mg} / \mathrm{kg}$ to $108.7 \mathrm{mg} / \mathrm{kg}$, with an increase of $26.76 \%$ to $593.99 \%$, and KL had the largest increase, consistent with the trend of organic matter and total phosphorus content. Hydrolyzed nitrogen increased by $0.2 \mathrm{mg} / \mathrm{kg}$ to $156.79 \mathrm{mg} / \mathrm{kg}$, with an increase of $1.14 \%$ to $420.24 \%$, consistent with the trend of organic matter and total nitrogen content, but RX decreased by $27.22 \%$. Available potassium increased by $19.23 \mathrm{mg} / \mathrm{kg}$ to $109.45 \mathrm{mg} / \mathrm{kg}$, with an increase of $15.48 \%$ to $103.30 \%$, the growth rate of YF was the largest, which was the result of long-term application of biogas slurry, while TZY decreased by $25.13 \%$. The nitrate nitrogen content of XJ, YF, JX, RX and MD increased by $5.85 \mathrm{mg}$ to $43.27 \mathrm{mg} / \mathrm{kg}$, with and increase of $8.09 \%$ to $187.00 \%$ respectively, while YL, FR, GX, KL, TZY and SGL decreased by $0.8 \mathrm{mg}$ to $51.42 \mathrm{mg} / \mathrm{kg}$, with an increase of $1.00 \%$ to $81.04 \%$ respectively.

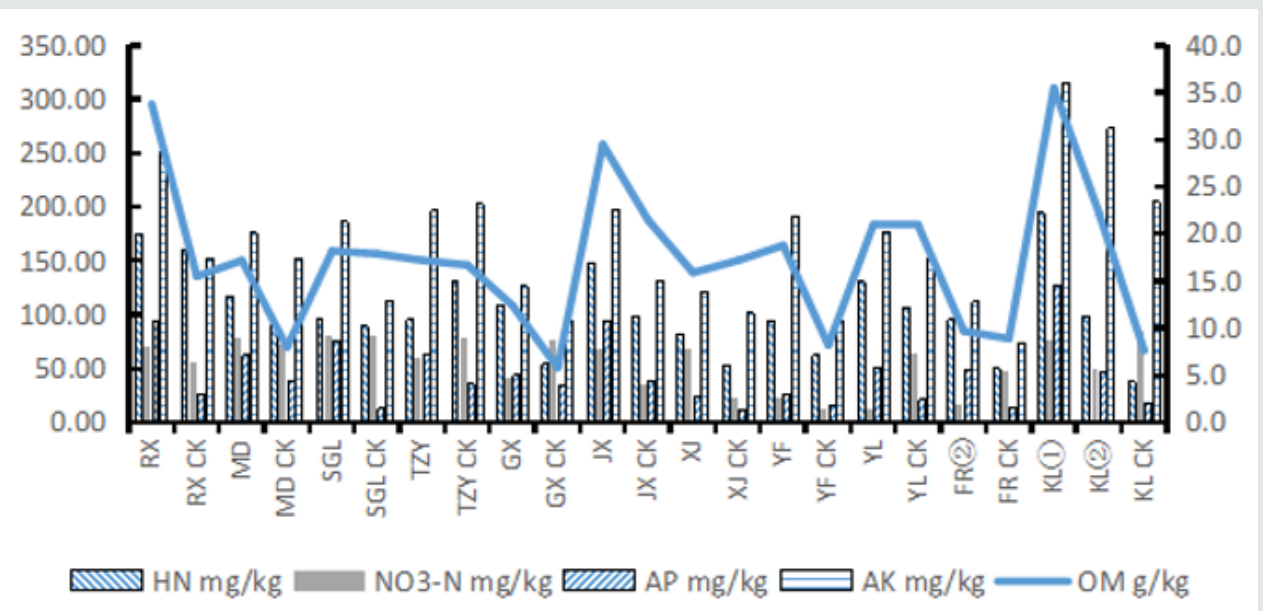

Figure 3: Effect of biogas slurry application on soil HN, AP and AK (mg $\backslash \mathrm{kg}$ ).

From the time of biogas slurry utilization, the change of available nitrogen, phosphorus and potassium is greater than that of total phosphorus and organic matter. The hydrolyzed nitrogen of greenhouse vegetable is $\mathrm{KL}>\mathrm{JX}>\mathrm{RX}>\mathrm{MD}$, the available phosphorus is $\mathrm{KL}>\mathrm{RX}>\mathrm{JX}>\mathrm{MD}$, the available potassium of soil is $\mathrm{RX}>\mathrm{KL}>\mathrm{JX}>$ $\mathrm{MD}$, and the change trend of available phosphorus is consistent with that of total phosphorus. The hydrolyzed nitrogen of grain economy planting is $\mathrm{GX}>\mathrm{YF}>\mathrm{SGL}$, the available phosphorus is $\mathrm{SGL}>\mathrm{YF}>\mathrm{GX}$, the available potassium is $\mathrm{YF}>\mathrm{SGL}>\mathrm{GX}$. The soil hydrolyzed nitrogen in the orchard is $\mathrm{FR}>\mathrm{YL}>\mathrm{XJ}>\mathrm{TZY}$, the soil available phosphorus was $\mathrm{FR}>\mathrm{YLG}>\mathrm{XJ}>\mathrm{TZY}$, the soil available potassium was $\mathrm{FR}>\mathrm{XJ}>\mathrm{YL}$ $>\mathrm{TZY}$, and the changing trend of hydrolyzed nitrogen is the same with that of the total nitrogen.

\section{Effect of biogas slurry utilization on Soil Hydrolase}

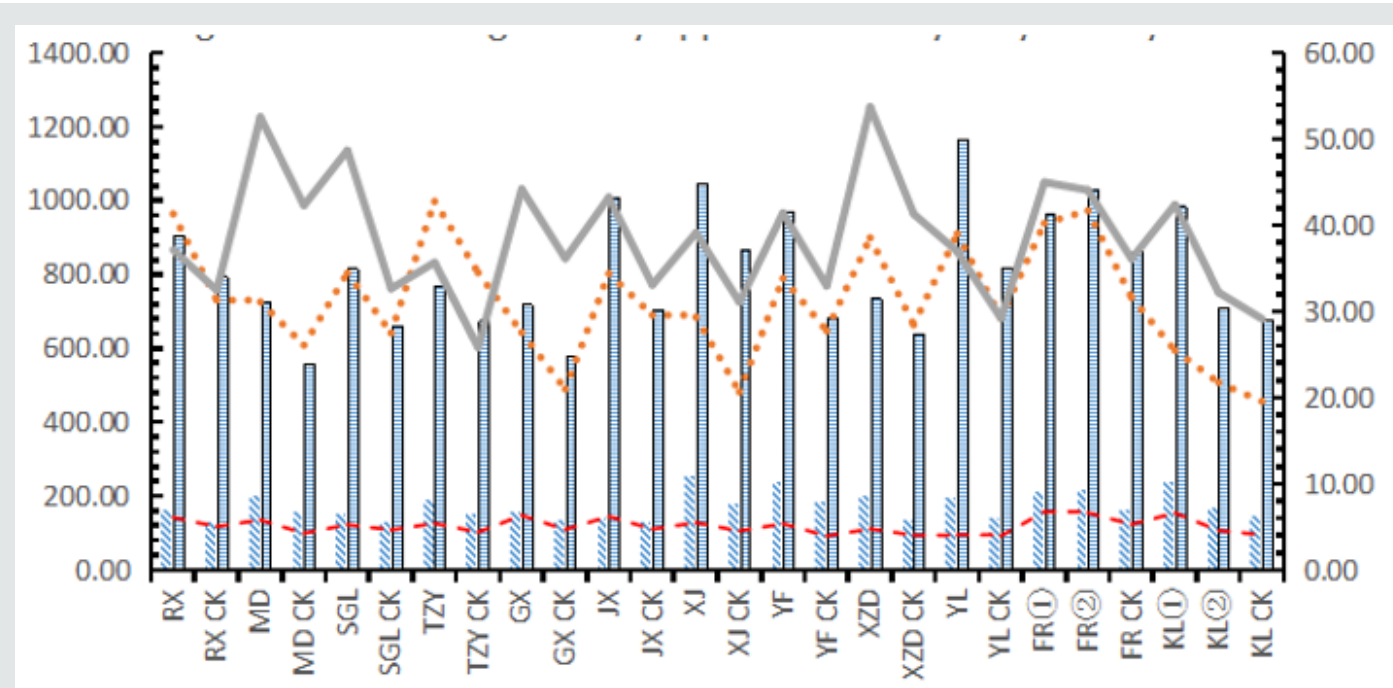

.IIIII) Protease $\square$ Acid phosphatase.... Sucrase —U Urease - - - Cellulase

Figure 4: Effect of biogas slurry application on hydrolytic enzymes. 
Soil enzyme activity is one of the important indexes of soil biological activity and soil fertility. Soil Hydrolase mainly includes protease, phosphatase, sucrase, urease, cellulase, etc. they play an important role on catalyzing the biochemical reaction in the soil, such as the decomposition and transformation of soil organic matter, directly participating in soil $\mathrm{C}$ and $\mathrm{N}$ cycle, nutrients use, improving soil fertility and nitrogen recycling. Invertase is closely related to the total nitrogen content of soil, phosphatase is closely related to the hydrolysis and activation of organic phosphorus, and urease is involved in soil fertility and nitrogen cycle [26], The utilization of biogas slurry can significantly improve the activities of soil protease, acid phosphatase, sucrase, urease, cellulase and other hydrolases (Figure 4). Compared with the control farmland, the protease increased by $0.49-4.02 \mathrm{IU} / \mathrm{L}$, with an increase of 8.77$64.42 \%$, the highest among of them was KL greenhouse vegetables. The sucrase increased by 51.34-235.25IU/L, with an increase of 11.24-41.83\%, which the largest increase was in FR farmland and XJ vineyard. The Urease increased by $71.78-374.54 \mathrm{IU} / \mathrm{L}$, with an increase of $10.55-49.12 \%$, which the most increase was the rotation of grain and vegetable in SGL. The acid phosphatase increased by $1.49-14.77 \mathrm{IU} / \mathrm{L}$, with an increase of $5.16-45.86 \%$, which the most increase was YL vineyard and KL greenhouse vegetable. The cellulase increased by 2.51-58.81IU/L, with an increase of 2.72$61.40 \%$, which the most increase was KL greenhouse vegetable.

\section{Effect of Biogas Slurry Utilization on Soil Oxidoreductase}

Soil reductase mainly includes dehydrogenase, catalase, nitrate reductase, nitrite reductase, sulfuric acid reductase, etc. It mainly affects soil physical and chemical properties and soil fertility [26], such as reducing the harm of hydrogen ions and activating soil nutrients. Biogas slurry utilization can significantly improve the activity of dehydrogenase, catalase, nitrate reductase and nitrite reductase (Figure 5). Compared with the control farmland, the nitrate reductase increased by $0.48-9.82 \mathrm{IU} / \mathrm{L}$, with an increase of 3.51-55.95\%, which the highest increase was in GUOXING farmland. The nitrite reductase increased by $0.73-12.89$ IU/L, with an increase of 2.34-51.47\%, which the most increase was XZD farmland and KL greenhouse vegetables, but it decreased by 6.65IU/L and 0.02IU/L in FR vineyard and XJ vineyard respectively, with a decrease of $21.28 \%$ and $0.11 \%$ respectively. The dehydrogenase increased by $0.11-3.88 \mathrm{IU} / \mathrm{L}$, with an increase of $3.51-62.19 \%$, which the most increase was $\mathrm{KL}$ greenhouse vegetables and FR vineyard. The catalase increased by 2.93-32.77IU/L, with and increase of 4.33$46.18 \%$, which the most increase was YL vineyard and YF farmland.

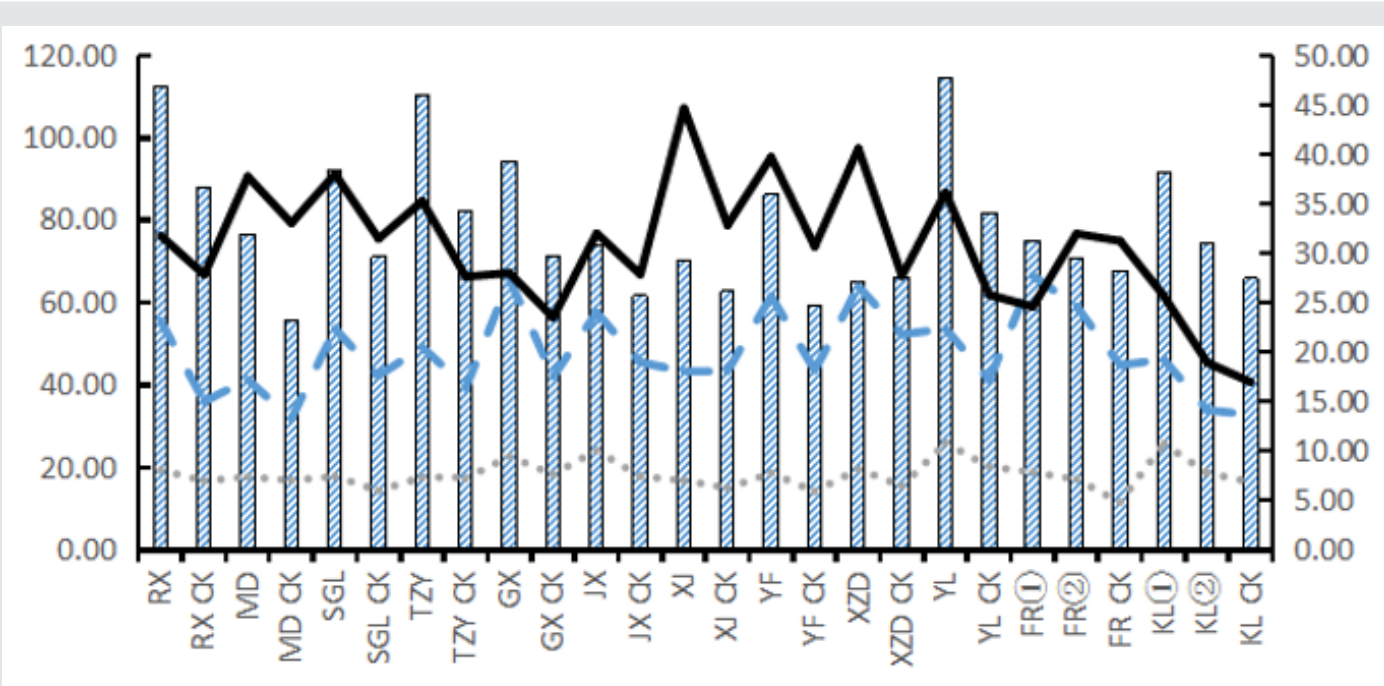

WII Dehydrogenase - - Nitrate reductase - Nitrite reductase .... Catalase

Figure 5: Effect of biogas slurry application on REDOX enzymes.

\section{Correlation of Soil Nutrient and Enzyme Activity}

There are different correlations between nutrients and soil enzymes in the plough layer of soil (Table 2). Between soil organic matter and $\mathrm{N}, \mathrm{P}$ and $\mathrm{K}$, the content of soil organic matter has a significant positive correlation with total N, hydrolyzed N, available $\mathrm{P}$ and available $\mathrm{K}$, and has a significant correlation with total $\mathrm{P}$. The total $\mathrm{N}$ has a significant correlation with total P, hydrolyzed $\mathrm{N}$, available $\mathrm{P}$ and available $\mathrm{K}$, and has a significant correlation with total $\mathrm{K}$. The total $\mathrm{P}$ has a significant correlation with hydrolyzed $\mathrm{N}$ and available $\mathrm{P}$. The total $\mathrm{K}$ has a significant correlation with available potassium. The hydrolyzed nitrogen and available potassium, and available phosphorus and available potassium has a significant correlation. Among soil nutrients and soil enzymes, soil organic matter content was significantly positively correlated with oxidase and dehydrogenase, and significantly correlated with acid phosphatase and cellulase. Total nitrogen was significantly correlated with cellulase, catalase and dehydrogenase. Total phosphorus was significantly correlated with dehydrogenase and sucrase. Total potassium was significantly correlated with catalase and dehydrogenase, and significantly correlated with acid phosphatase and nitrate reductase. The hydrolyzed nitrogen was significantly correlated with cellulase, catalase and dehydrogenase. 
The available P was significantly correlated with urease, cellulase, was significantly correlated with nitrate reductase, catalase, catalase and dehydrogenase, and significantly correlated with sucrase, acid phosphatase and nitrate reductase. Available $\mathrm{K}$

\section{dehydrogenase, and cellulase.}

\begin{tabular}{|c|c|c|c|c|c|c|c|c|c|c|c|c|c|c|c|c|c|}
\hline 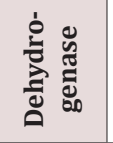 & & & & & & & & & & & & & & & & & $\neg$ \\
\hline 䒕 & & & & & & & & & & & & & & & & $\rightarrow$ & $\begin{array}{l}\text { * } \\
\text { * } \\
\text { L } \\
\text { Ln } \\
0\end{array}$ \\
\hline 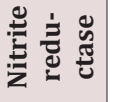 & & & & & & & & & & & & & & & $\rightarrow$ & 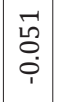 & $\underset{0}{m}$ \\
\hline 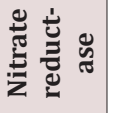 & & & & & & & & & & & & & & $r$ & 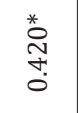 & \begin{tabular}{l}
$*$ \\
\multirow{2}{0}{} \\
\multirow{7}{*}{} \\
0
\end{tabular} & $\begin{array}{l}* \\
\infty \\
\infty \\
+ \\
+ \\
0\end{array}$ \\
\hline $\begin{array}{l}\dot{\Xi} \\
\text { 志 } \\
\text { : }\end{array}$ & & & & & & & & & & & & & -1 & 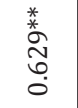 & 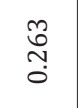 & $\begin{array}{c}\hat{N} \\
\tilde{0} \\
0\end{array}$ & 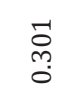 \\
\hline 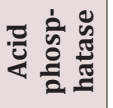 & & & & & & & & & & & & - & 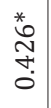 & 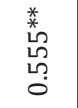 & 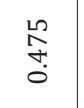 & 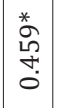 & $\stackrel{\stackrel{*}{\sim}}{\underset{\ddagger}{0}}$ \\
\hline 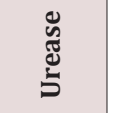 & & & & & & & & & & & $-r$ & $\begin{array}{l}\text { ஸे } \\
\text { ஸे }\end{array}$ & $\begin{array}{l}\text { 菜 } \\
\stackrel{0}{0} \\
0 \\
0\end{array}$ & \begin{tabular}{l}
$\stackrel{*}{*}$ \\
\multirow{+}{+}{} \\
0
\end{tabular} & $\begin{array}{l}\stackrel{*}{\oplus} \\
\text { N̦} \\
\text { ஸै }\end{array}$ & 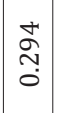 & $\stackrel{\text { Ln }}{\stackrel{0}{0}}$ \\
\hline 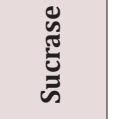 & & & & & & & & & & -1 & 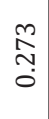 & $\begin{array}{l}\stackrel{*}{*} \\
\stackrel{\circ}{\circ} \\
\stackrel{2}{0} \\
0\end{array}$ & $\begin{array}{l}\tilde{N} \\
\tilde{\sigma} \\
\sigma\end{array}$ & $\begin{array}{l}\text { * } \\
\text { Ln } \\
\text { Ln } \\
0\end{array}$ & 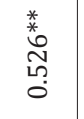 & 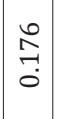 & \begin{tabular}{l} 
* \\
\multirow{2}{*}{} \\
$\stackrel{0}{6}$ \\
0 \\
0
\end{tabular} \\
\hline 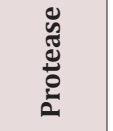 & & & & & & & & - & & 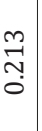 & $\begin{array}{c}\infty \\
\tilde{m} \\
0\end{array}$ & $\begin{array}{l}\text { *. } \\
0 \\
0 \\
0 \\
0 \\
0 \\
0\end{array}$ & \begin{tabular}{l}
0 \\
\multirow{2}{0}{} \\
0
\end{tabular} & ָั & 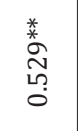 & 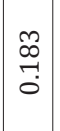 & $\begin{array}{l}\text { में } \\
\text { ने }\end{array}$ \\
\hline 产 & & & & & & & - & ๙ิ & & 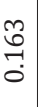 & $\begin{array}{c}\infty \\
\stackrel{\sim}{N} \\
0 \\
0\end{array}$ & $\begin{array}{l}\text { Ò } \\
\text { N̦ } \\
0\end{array}$ & \begin{tabular}{l}
$*$ \\
\multirow{6}{0}{} \\
$\stackrel{+}{0}$ \\
0
\end{tabular} & $\begin{array}{l}\stackrel{*}{*} \\
\text { N } \\
\text { นุ } \\
0\end{array}$ & $\begin{array}{l}n \\
0 \\
0 \\
\end{array}$ & 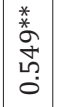 & 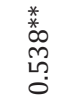 \\
\hline$\stackrel{e}{\alpha}$ & & & & & & - & 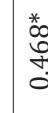 & $\begin{array}{l}m \\
m \\
c\end{array}$ & 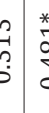 & \begin{tabular}{l}
$\stackrel{*}{*}$ \\
$\infty$ \\
\multirow{+}{*}{} \\
0
\end{tabular} & \begin{tabular}{l}
$*$ \\
\multirow{2}{*}{} \\
$\infty$ \\
10 \\
0 \\
0
\end{tabular} & $\begin{array}{l}\stackrel{*}{*} \\
\stackrel{\sim}{\ddagger} \\
0\end{array}$ & 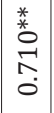 & \begin{tabular}{l}
$\stackrel{*}{\infty}$ \\
\multirow{+}{+}{} \\
0
\end{tabular} & $\underset{\stackrel{+}{N}}{\stackrel{N}{0}}$ & $\begin{array}{l}\text { 悉 } \\
\stackrel{5}{6} \\
\stackrel{0}{0}\end{array}$ & 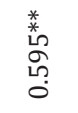 \\
\hline 齐 & & & & & - & 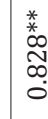 & $\begin{array}{l}* \\
\infty \\
5 \\
0 \\
0\end{array}$ & $\stackrel{\overbrace{}}{\tilde{c}}$ & & 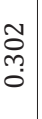 & $\stackrel{m}{0}$ & 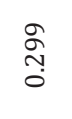 & $\mid$\begin{tabular}{l}
$*$ \\
\multirow{*}{*}{} \\
Ln \\
0 \\
0
\end{tabular} & ஸे & $\stackrel{-}{0}$ & $\mid \begin{array}{l}* \\
\stackrel{*}{*} \\
\stackrel{1}{\hat{L}} \\
0 \\
0\end{array}$ & $\begin{array}{l}\text { * } \\
\stackrel{*}{*} \\
\text { L } \\
0\end{array}$ \\
\hline$\stackrel{y}{\prime}$ & & & & - & $\begin{array}{c}\text { mे } \\
\text { m. } \\
0\end{array}$ & ำ & $\stackrel{*}{m}$ & $\stackrel{7}{7}$ & 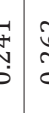 & 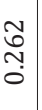 & $\begin{array}{l}m \\
0 \\
0 \\
0 \\
1\end{array}$ & $\begin{array}{l}\stackrel{*}{\stackrel{*}{n}} \\
\text { ?ִ } \\
0\end{array}$ & $\begin{array}{l}\stackrel{0}{\tilde{m}} \\
0 \\
0\end{array}$ & 苾 & $\underset{\stackrel{0}{~}}{\stackrel{0}{0}}$ & \begin{tabular}{l} 
* \\
\multirow{2}{*}{} \\
0 \\
$\vdots$ \\
0
\end{tabular} & $\begin{array}{l}\stackrel{*}{*} \\
\stackrel{*}{\circ} \\
\stackrel{0}{0} \\
0\end{array}$ \\
\hline$\stackrel{1}{\circ}$ & & & -1 & $\begin{array}{l}\text { N } \\
\text { mె } \\
0\end{array}$ & 蒾 & 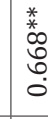 & 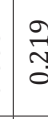 & 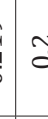 & \& & 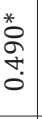 & $\begin{array}{c}\infty \\
\stackrel{\sim}{N} \\
0 \\
0\end{array}$ & $\underset{\stackrel{m}{+}}{\stackrel{\mathfrak{\sigma}}{0}}$ & 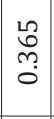 & 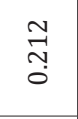 & 咅 & $\begin{array}{l}\frac{L}{N} \\
\\
0\end{array}$ & 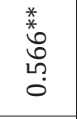 \\
\hline Z & & $\neg$ & \begin{tabular}{l}
$*$ \\
\multirow{*}{*}{} \\
$\sigma$ \\
\multirow{2}{0}{} \\
0
\end{tabular} & $\begin{array}{l}\stackrel{*}{m} \\
\stackrel{1}{\Xi} \\
0\end{array}$ & 悉 & \begin{tabular}{l}
$*$ \\
\multirow{*}{*}{} \\
0 \\
0 \\
0 \\
0 \\
0
\end{tabular} & 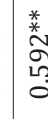 & 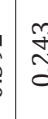 & 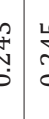 & $\begin{array}{l}\stackrel{\sim}{+} \\
\stackrel{+}{*} \\
0\end{array}$ & $\begin{array}{c}\stackrel{\sigma}{\vec{n}} \\
\stackrel{\sigma}{\sigma}\end{array}$ & $\stackrel{\text { m}}{\circ}$ & 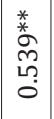 & $\begin{array}{l}\hat{\omega} \\
\text { ñ } \\
0\end{array}$ & $\begin{array}{l}\hat{0} \\
\text { 웅 } \\
\text { i }\end{array}$ & $\begin{array}{l}\underset{*}{*} \\
\hat{*} \\
\infty \\
\vdots \\
0 \\
0\end{array}$ & $\stackrel{*}{*}$ \\
\hline$\sum_{0}$ & $\rightarrow$ & \begin{tabular}{l}
$\stackrel{*}{*}$ \\
\multirow{\sigma}{N}{} \\
$\sigma$
\end{tabular} & $\stackrel{*}{\sim}$ & 葲 & 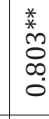 & $\stackrel{\stackrel{*}{*}}{\stackrel{N}{N}}$ & 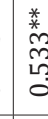 & $\frac{6}{d}$ & & $\begin{array}{l}\text { 亡ี } \\
\text { ஸे } \\
0\end{array}$ & $\begin{array}{l}\infty \\
0 \\
-1 \\
0 \\
0\end{array}$ & 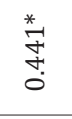 & \begin{tabular}{c}
$*$ \\
\multirow{0}{0}{} \\
\multirow{2}{+}{} \\
0
\end{tabular} & مे & $\stackrel{m}{\stackrel{M}{+}}$ & 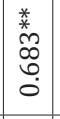 & 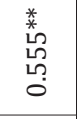 \\
\hline 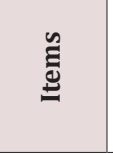 & $\sum$ & $\underset{H}{Z}$ & $\stackrel{?}{\epsilon}$ & $\stackrel{\mathscr{F}}{\mathrm{F}}$ & 壱 & 安 & 运 & 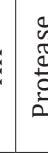 & 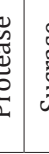 & 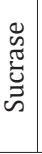 & $\begin{array}{c}0 \\
\tilde{z} \\
\tilde{0} \\
\vdots \\
5\end{array}$ & 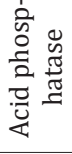 & 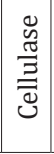 & 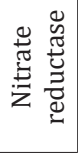 & 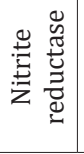 & $\begin{array}{l}0 \\
\tilde{w} \\
\frac{\pi}{\pi} \\
\tilde{J} \\
\tilde{J}\end{array}$ & 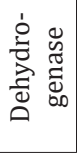 \\
\hline
\end{tabular}


Among soil enzymes, the protease was positively correlated with acid phosphatase and nitrite reductase. Sucrase was positively correlated with nitrate reductase, nitrite reductase, dehydrogenase, and acid phosphatase. Urease was positively correlated with cellulase, but significantly correlated with nitrate reductase and nitrite reductase. Cellulase was positively correlated with nitrate reductase. Nitrate reductase was significantly correlated with nitrite reductase, catalase and dehydrogenase. Catalase and dehydrogenase showed a significant positive correlation.

\section{Results and Discussion}

a. The content of organic matter, nitrogen, phosphorus and potassium in biogas slurry in different enterprises is different, which affects the significant difference in the accumulation amount in the surface soil. Compared with farmland without biogas slurry, biogas slurry utilization effectively improved the soil $\mathrm{pH}$ value, increased the surface organic matter, total nitrogen, total potassium, total phosphorus, available nitrogen, nitrate nitrogen, available phosphorus and available potassium, which is influenced by the utilization, irrigation quantity and irrigation times. The organic matter, total nitrogen and total potassium of greenhouse vegetables showed $\mathrm{KL}>\mathrm{RX}>\mathrm{MD}>$ JX, while the total phosphorus of the soil increased with the extension of utilization time, namely $\mathrm{KL}>\mathrm{RX}>\mathrm{JX}>\mathrm{MD}$. The organic matter, total nitrogen and total phosphorus of grain economy plant showed as $\mathrm{YF}>\mathrm{GX}>\mathrm{SGL}$, and the total potassium of them showed as guoxing GX $>\mathrm{YF}>\mathrm{SGL}$. The orchard is relatively complicated, the soil organic matter is $\mathrm{FR}>\mathrm{TZY}>\mathrm{YL}>\mathrm{XJ}$, the total $\mathrm{N}$ is $\mathrm{FR}>\mathrm{YL}>\mathrm{XJ}>\mathrm{TZY}$, the total phosphorus is $\mathrm{XJ}>\mathrm{YL}>\mathrm{FR}>\mathrm{TZY}$, and the total potassium is $\mathrm{YLG}>\mathrm{XJ}>\mathrm{TZY}>\mathrm{FR}$. The results of this study are basically consistent with the research results applied biogas slurry during the growth period of wheat [20], and that longterm or short-term application of biogas slurry is conducive to increasing nitrogen, phosphorus, potassium and other soil nutrients $[1,3,5]$.

b. Biogas slurry utilization can significantly improve the activity of hydrolytic enzymes. Hao X.J. et al [27] applied biogas slurry to improve the activity of hydrolytic enzymes such as soil sucrase, phosphatase and protease, and Geng C.G. et al [18] digested biogas slurry in the garden can significantly improve the activity of soil sucrase and urease, but the changes of acid phosphatase and catalase are not significant. Guan T. et al [28] biogas slurry irrigation can significantly improve soil urease activity and reduce catalase activity. The combination of biogas slurry with nitrogen significantly increased soil urease and dehydrogenase activity in peanut pod and harvest stages [19]. Wang H.W. et al [20] biogas slurry applied to wheat increased soil catalase, alkaline phosphatase and urease activity, the combination of biogas slurry with potash fertilizer in apple orchard significantly improved fruit quality and soil enzyme activity. And the results of this study was to enhance the activity of all hydrolases and REDOX enzymes. The protease increased by 8.77 to $64.42 \%$, invertase increased by 11.24 to $41.83 \%$, urease increased by 10.55 to $49.12 \%$, acid phosphatase increased by 5.16 to $45.86 \%$, cellulose enzyme increased by 2.72 to $61.40 \%$, increased by 3.51 to $55.95 \%$ of nitrate reductase, Nitrite reductase increased by $2.34-51.47 \%$, dehydrogenase increased by $3.51-62.19 \%$, and catalase increased by $4.33-46.18 \%$, which might be the use of biogas slurry, improved soil microbial environment, such as organic matter composition, NPK ratio and pH value, thus stimulating the growth of the microorganisms and microflora balance [29], improved the soil hydrolase and REDOX enzyme activity, in turn, enzyme activity improve the soil nutrient cycling and biological activity, improve soil fertility.

c. soil enzyme activity reflects the nutrient transformation capacity in the soil, and soil nutrient content reflects the fertility level of the soil, and there is a significant correlation between them [30]. Urease activity had the best correlation with soil nutrients [31]. The results showed that soil organic matter, nitrogen, phosphorus, potassium content of oxygen and hydrogen enzyme, dehydrogenase and acid phosphatase, cellulase, sucrase, nitrate reductase were significantly or extremely significantly correlated, the soil organic matter, NPK, catalase and dehydrogenase activity were significantly positive correlation, soil total nitrogen, hydrolyze nitrogen, available phosphorus and cellulase were very significant positive correlation, and organic matter, available potassium have significant correlation relationship with cellulase. At the same time, there were significant or extremely significant correlations between different soil enzymes.

\section{Conclusion}

Through the analysis of biogas slurry nutrients, soil nutrients, soil enzyme activity and its correlation, it is shown that biogas slurry plays an active role in soil surface nutrient accumulation, especially the accumulation of available phosphorus and available potassium, and improves all of soil hydrolase and REDOX enzyme activity. There are significant or extremely significant correlations between soil nutrients and soil enzymes activity, especially the soil organic matter, NPK, catalase and dehydrogenase activity were significantly positive correlation, soil total nitrogen, hydrolyze nitrogen, available phosphorus and cellulase were very significant positive correlation, and organic matter, available potassium have significant correlation relationship with cellulase.

\section{Acknowledgments}

This work is supported by the National Key Point Research and Invention Program (2017YFD0301102).

\section{References}

1. Galvez A, Sinicco T, Cayuela ML, Mingorance MD, Mondini C, et al. (2012) Short term effects of bio-energy by-products on soil $\mathrm{C}$ and $\mathrm{N}$ dynamics, nutrient availability and biochemical properties[J]. Agriculture, Ecosystems and Environment 160: 3-14.

2. Zirkler D, Peters A, Kaupenjohann M (2014) Elemental composition of biogas residues: Variability and alteration during anaerobic digestion. J Biomass \& Bioenergy 67: 89-98.

3. Marls T, Lithour Gidis AS, Gagianas AA (2003) Effects of injected liquid cattle manure on Growth and Yield of Winter Wheat and soil Characteristics. J Agron J 95(3):592-596. 
4. Chen N, Gao TG, Jiang F (2011) Effects of nutrition stabilized biogas slurry fertilization on yield and quality of winter wheat. Chinese Biogas 29(4): 47-50

5. Garg R N, Pathak H, Das DK,Tomar RK (2005) Use of Fly ash and Biogas Slurry for Improving Wheat Yield and Physical Properties of Soil[J]. Environ Monit Assess 107(1-3): 1-9.

6. Wu JC, Pan YX, Yang YH (2019) Effects of Integration of Water and Fertilizer Application of Chemical Fertilizer and Biogas Fertilizer Combination on the Yield of Wheat and WUE. Soi Sci 7(40): 262-269.

7. Kong DJ, Yang GH, Ren G (2008) Effects of Different Amount of Applied Biogas Fermentation Residues on Photosynthesis Characteristic and Grain Yield of Winter Wheat. Acta Agri Boreali-occidentalis Sinica 17(2): 64-69.

8. Feng W, Guan T, Wang YH, Zhu YJ, Tian-Cai G, et al. (2010) Effects of biogas slurry combinated with urea on hotosynthetic charcteristics and grain yield of winter wheat. Acta Agronomica Sinica 36(8): 1401-1408.

9. Li BZ, Wang GF, Qin XF (2010) Effects of application of biogas slurry with potassium on orchard soil properties and soil microorganism and fruit quality. Sci Agric Sinica 3(22): 4671-4677.

10. Feng W, Qiu JD, Guan T (2011) Effects of topdressing amount of biogas slurry on wheat protein components, flour rheological and paste parameters of wheat. J of Triticeae Crops 31(2): 276-280

11. Lu WL (2011) Effects of biogas slurry application on wheat yield, quality and soil quality. Ya 'an: Sichuan Agricultural University.

12. Garcia F, Cruse RM, Blackmer A M (1988) Compaction and nitrogen placement effect on root growth, water depletion, and nitrogen uptake[J]. Soil Science Society American Journal 52(3):792-798.

13. Olesen J E, Askegaard M, Rasmussen IA (2009) Winter cereal yields as affected by animal manure and green manure in organic arable farming[J]. European journal of agronomy 30 (2): 119-128.

14. Sarker MA, Itohara Y, Hoque M, Sarder N (2011) Scope and challenges of organic wheat cultivation in Bangladesh[J]. Australian Journal of Crop Science. Wheat Special Issue 5(9): 1114-1119.

15. Sieling K, Herrmann A, Wienforth B, Friedhelm T, Susanne O, et al. (2013) Biogas cropping systems: Short term response of yield performance and $\mathrm{N}$ use efficiency to biogas residue application[J]. European Journal of Agronomy, 47: 44-54.

16. Terhoeven-Urselmans T, Scheller E, Raubuch M, Rainer Georg J (2009) CO2 evolution and $\mathrm{N}$ mineralization after biogas slurry application in the field and its yield effects on spring barley[J]. Applied Soil Ecology 42(3): 297-302.

17. Abubaker J, Risberg K, Pell M (2012) Biogas residues as fertilizers Effects on wheat growth and soil microbial activities. J Applied Energy 99: 126134.
18. Geng CG, Duan JJ, Li X (2012) Short-term effects of biogas slurry application to garden land on soil microbial biomass carbon \& nitrogen and soil enzymes. J of Agro-Environment Sci 31(10): 1965-1971.

19. Zheng XB, Fan JB, He YQ, Cui J, Xu L, et al. (2015) Effect of total nitrogen ratio of biogas slurry/chemical fertilizer on microflora and enzyme activities of soil. Transactions of Chinese Society of Agri Engin 31(19): $142-150$

20.Wang HW, Jia LL, Zhao JQ (2017) Effects of biogas slurry on photosynthetic characteristics, soil enzyme activity and nutrient content of winter wheat. J of Northwest A\&F University (Natural Science Edition) 45(1): 35-44.

21. Liu SJ, Xia X, Chen GM (2011) Study progress on functions and affecting factors of soil enzymes. Chinese Agri Sci Bulletin 27(21): 1-7.

22. Dahiya AK, Vasudevan P (1986) Biogas slurry as an alternative to chemical fertilizer. Biomass 9(1): 67-74.

23. Jiang LN, Wang Q, li AF (2011) The ecological effects of fallow paddy field disposal biogas slurry and its impact on the following rice safety production. J of Agro Environment Sci 30(12): 2483-2490.

24. Wang GF, Li BZ, Zhang LS (2009) Effects of application of biogas slurry with potassium on soil enzyme activity and quality of red Fuji apple. J of Northwest Forestry University 24(5): 88-91.

25. Bi ML, Yu WT, Jiang ZS (2010) Effects of fertilization and soil management on microbial biomass and community. Acta Eco Sinica 30(1): 32-42.

26. Guan SY (1986) Soil enzyme and its research method. Beijing Agricultural Press pp.

27. Hao XJ, Hong JP, Qiao ZW (2011) Effect of biogas slurry on biological properties of cabbage continuous cropping Soil. Chinese Journal of Applied and Environmental Biology 17(3): 384-387.

28. Guan T, Feng W, Wang HQ (2010) Effect of topdressing amount of biogas slurry on soil microorganisms and enzyme activities in winter wheat. Journal of Triticeae Crops 30(4): 721-726.

29. Vepsäläinen M, Kukkonen S, Vestberg M (2001) Application of soil enzyme activity test kit in a field experiment. Soil Biology \& Biochemistry 33(12): 1665-1672.

30. Ma RR, Gao XL, Cui WW (2013) Research on Soil Nutrient and Soil Enzyme in Kidney Bean Field with Continuous Cropping. Acta Agri Boreali sinica 28(5): 157-162.

31. Feng AQ, Zhang M, Li CL (2014) Effects of controlled release nitrogen fertilizer on soil enzyme activity and soil nutrient utilization. J of water and soil conservation 28(3): 177-184.

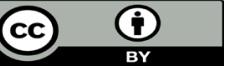

This work is licensed under Creative Commons Attribution 4.0 License

To Submit Your Article Click Here: Submit Article
DOI: $10.32474 / C I A C R .2020 .08 .000286$

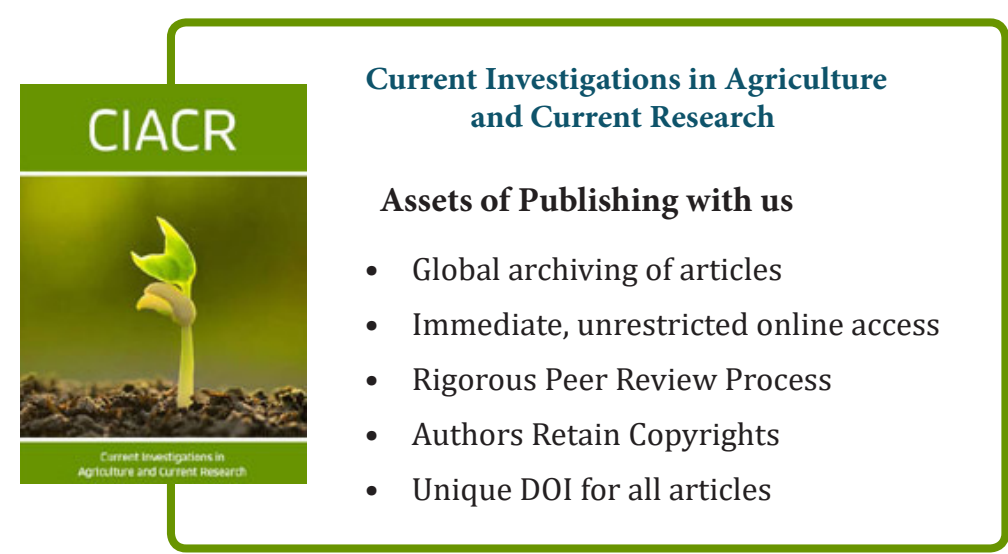

